\title{
Antihyperlipidemic Effect of Alcoholic Seed Extract of Caesalpinia bonduc (Lin.) Roxb. In Alloxan Induced Diabetic Male Albino Rats
}

\author{
Vedavyasa Sagar \\ Assistant Professor, \\ Department of Zoology, \\ Veerashaiva College, Ballari, Karnataka, India. \\ vedavyassgar@gmail.com
}

\author{
R. Nazeer Ahamed \\ PG Department of Studies and Research in \\ Zoology, Karnatak University, Dharwad, \\ Karnataka, India \\ drnazeerahmed@yahoo.com
}

\begin{abstract}
Hypolipidemic property of alcoholic seed extract of Caesalpinia bonducella (ASECB) and its effect on total protein level was tested in alloxan induced diabetic male albino rats. A significant $(P<0.05)$ increase in the levels of Total cholesterol (TC), Triglyceride (TG), Low density lipoprotein (LDL), Very low density lipoprotein $(V L D L)$ and significant $(P<0.05)$ decrease in High density lipoprotein $(H D L)$ were observed in diabetic control rats. Oral supplementation of ASECB to diabetic rats for 21 days results in significant $(P<0.05)$ fall in TC, TG, LDL, VLDL level and significant $(P<0.05)$ elevation in $H D L$ was noticed. The concentration of total protein in serum of induced diabetic rats declined significantly $(P<0.05)$. On oral administration of ASECB to diabetic rats, protein level in serum increased significantly $(P<0.05)$. The values of lipid profile and total protein of normal rats which are administered with different doses of ASECB was not significantly altered, indicating that the plant extract has no side effects. Higher dose $(400 \mathrm{mg})$ is more effective than lower dose $(200 \mathrm{mg})$ in restoring the normal lipid.profile and total protein. The disturbed lipid profile and decreased protein level noticed in diabetic animals get almost normalized due to ASECB treatments. Thus, it is suggested ASECB could serve as a good oral hypolipidemic agent
\end{abstract}

Keywords: Alloxan; Caesalpinia bonducella; Cholesterol; Diabetes mellitus; Hypolipidemic; Triglyceride.

\section{INTRODUCTION}

Diabetes is a most common, metabolic, hereditary and endocrine disorder which affects large number of population all over the world. Medically this disorder is known as Diabetes Mellitus (DM). It is characterized by the deficiency in production of insulin by the endocrine pancreas leading to excess glucose in blood and in urine. Chronic hyperglycemia during diabetes causes glycation of body proteins that in turn lead to secondary complications affecting eyes, kidney, heart, nerves, blood vessels, liver and many other vital organs. The symptoms of diabetes are increased blood sugar, bodyweight loss, weakness, frequent urination, severe thirst, blurred vision, extreme hunger, extreme fatigue, tiredness, numbness in the hand or feet, recurring gum and skin infections, etc. Long-term complications of DM results in loss of vision, loss of kidney function, foot ulcers, heart disease, stroke, sexual dysfunction, amputation of lower extremities and may even lead to coma.

$\mathrm{DM}$ is a chronic lifelong disease that can be treated but not cured. Though both men and women can be affected by DM, the rate of DM in women has increased considerably in the recent years. DM is a silent killer. If uncontrolled, it can lead to deadly complications.

A world wide survey reported that DM is affecting nearly $10 \%$ of the population every year (Vetrichelvan et. al., 2002). According to World Health Organization (WHO), the diabetic population is likely to increase to 300 million or more by the year 2025 (Boyle et. al., 2001). The number of people suffering from the disease worldwide is increasing at an alarming rate with projected 366 million peoples likely to be diabetic by the year 2030 as against 191 million estimated in 2000 (Wild et. al., 2004). This disease is the seventh leading cause of death in the world. Every eight seconds somewhere in the world someone dies from diabetes. The number of 
people with diabetes multiplies worldwide. It is projected to become one of the world main disablers and killers within the next 25 years (Li WL et. al., 2004). The incidence of DM is high all over the world especially in Asia. The countries with largest number of DM are India, China and the United states (Hruban and Wilentz, 2004).

Recent studies on geographical and ethnic influences have shown that people of Indian origin are highly prone to diabetes. It is estimated that between $10-12 \%$ of the urban population and 4- 6\% of the rural population of India have diabetes now. One in every five urban adult Indians now suffer from DM. Statistical projections about India suggest that the number of diabetes will rise from 15 million in 1995 to 79.4 million by 2025 , making it the country with the highest number of diabetic in the world (King et. al., 1998, Boyle et. al., 2001). WHO has issued a warning that India will be the diabetic capital of the world. Based on etiology, DM is classified into Type-1 (IDDM-Insulin dependent DM), Type-2 (NIDDM-Non-insulin dependent DM) and Gestational Diabetes (GD).

Type- 1 is also called juvenile diabetes as it is commonly seen in children and teenagers. This occurs when the pancreas is unable to produce insulin, which is responsible to carry glucose to cells. This results in increase in glucose level in blood. People with Type-1 DM need to take insulin every day.

Type-2 diabetes is said to occur in middle-aged and older people. In this case, either the production of insulin is low or the pancreas does produce insulin, but the body becomes resistant to insulin. It is not able to use the insulin properly, leading to the presence of glucose in the blood. Only 5\% to $10 \%$ have Type- 1 and $90 \%$ to $95 \%$ have Type- 2 DM. The problems of Type- 2 diabetes are $8.7 \%$ in men, $7.8 \%$ in women.

Gestational diabetes occurs in pregnant women due to hormonal changes. Though GD does not stay after the baby is born, women who have GD during pregnancy are at higher risk of developing Type-2 diabetes later in their life.

Different types of oral hypoglycemic agents such as biguanides, sulphonylurea are available along with insulin for the treatment of DM (Holman and Turner, 1991). But side effects are associated with their uses (Rao et. al., 1997, Valiathan, 1998). Synthetic hypoglycemic drugs can produce side effects including coma, disturbances of liver and kidney function. In addition they are not suitable for use during pregnancy (Larner, 1985). Further insulin therapy has shortcomings such as need for constant refrigeration, it cannot be used orally and insulin injections are associated with the risk of fatal hypoglycemia in the event of excess dosage (Anuradha et. al., 2001) in which blood sugar level falls. A fall below $55 \mathrm{mg} / \mathrm{dL}$ produces severe symptoms leading to insulin shock and death. At present antidiabetic drugs like glimpiride, glipizzide, pioglitazone, rosiglitazone and metformin do not cure diabetes and produce side effects leading to other complications.

Plants are the important source of drugs, infact many of the currently available drugs were derived either directly or indirectly from the plants. Since ancient times, plant remedies have been used to relieve diabetes. In the 6th century BC Sushrutha, an Indian physician recommended plant remedies for the treatment of DM. Herbal remedies from medicinal plants have been used traditionally. Prior to discovery of insulin and other hypoglycemic synthetic drugs herbal medicine has been long used for the treatment of diabetic patients and they are currently accepted as an alternative therapy for diabetic treatment and control (Bailey, 1989). In many places throughout the world, DM is kept under control by the use of medicinal plant treatment, although this type of treatment has not been taken seriously by the medical field. Medicinal plants and their products have been widely used for treatments of DM all around the world with less known scientific basis of their functions (Patwardhan, 2004, Said et. al., 2007). The WHO says that the use of medicinal plants to treat DM is a topic that needs further research (Gray et. al., 1999). The WHO approves the use of plant drugs for different diseases including DM (Devaki et. al., 2011). There has been increasing demand for the use of plant products with antidiabetic activity due to low cost, easy availability and lesser side effects. There are more than 1200 plants worldwide that are used in the treatment of DM. The search for more effective and safer antidiabetic agent has become an area of active research. Although herbal medicines have long been used effectively in 
treating DM in Asian communities and throughout the world, yet the therapeutic efficacy, mechanism of action and safety of most of the herbals used has not been worked out. Only a small number of plants have received scientific and medical evaluation to assess their efficacy.

Caesalpinia bonduc (Lin.) Roxb. is a medicinal plant belonging to the family Fabaceae/ Caesalpiniaceae. Though hypolipidemic property of Caesalpinia bonduc (Lin,) Roxb. is reported, yet its therapeutic efficacy, its protective role against DM and its safety has not been worked out. Thus there is a need to investigate on this plant. Therefore, the present work was under taken and the main idea behind the present investigation is to show that the ASECB has antidiabetic, hypolipidemic effect and it can effectively be used to manage diabetic complications developed due to disturbed lipid profile.

\section{MAterials AND Methods}

\subsection{Venue}

The whole experimental work was conducted at the Post Graduate Department of Studies and Research in Zoology, Karnatak University, Dharwad, Karnataka, India.

\subsection{Experimental Animals Used}

Adult male albino rats of Wistar strain developed from Norwegian rat (Rattus norvegicus, Family: Muridae, Order: Rodentia) aged about 80-90 days, weighing between 200-240 g bred in animal house of Department of Post Graduate Studies and Research in Zoology, Karnatak University, Dharwad, India were selected as an experimental model in the present investigation. They were housed in individual polypropylene rat cages. The animal house was maintained at 64.4-78.8 $\mathrm{F}$ temperature and $40-70 \%$ relative humidity with 12 hours day-light/12 hours darkness schedule. The animals were checked daily to ensure that an adequate supply of food and water is available. The health and behavior was verified on a daily basis throughout the experimental period. The rats were fed with rat pellet feed supplied by M/s Krish Scientist's Shoppe, agents for scientist's choice laboratory animal feed, Bangalore, India, and water after ad-libitum throughout the experimental period. These are quite moderately prolific strain, rather resistant to infectious. The experiments were designed as per guidelines of Institutional Animal Ethics Committee (IAEC), vide Registration No. 639/ 02/a/CPCSEA.

\subsection{Induction of Diabetes}

Alloxan monohydrate $\left(\mathrm{C}_{4} \mathrm{H}_{2} \mathrm{~N}_{2} \mathrm{O}_{4} \mathrm{H}_{2} \mathrm{O}\right)$ was used as diabetes inducer in rats. The purpose of choosing alloxan monohydrate as diabetes-inducing agent was that it causes a massive reduction of the beta cells of the islets of langerhans and induces hyperglycemia (Sharma et. al., 2003). Best (1989) has also opined that alloxan, a beta cytotoxin, induces 'chemical diabetes' in a wide variety of animal species by damaging the insulin secreting cells (beta cells) of pancreas. Alloxan is well known for its selective pancreatic islet cell toxicity and has been extensively used in inducing DM in animals. DM was induced in normal healthy male albino rats by single intraperitonial freshly prepared injection of alloxan $(150 \mathrm{mg} / \mathrm{kg}$ body weight) (Desai and Bhide, $1985)$ dissolved in normal saline ( $2 \mathrm{ml} / \mathrm{kg} \mathrm{BW})$. The higher dose of alloxan usually caused death before severe diabetes could develop. The animals were allowed to fast for 12 hours prior to alloxan injection. After 3 days of alloxan injection, the glucose level was measured. Rats showing fasting glucose levels $>250 \mathrm{mg} / \mathrm{dL}$ were considered as diabetic and selected for the investigation.

\subsection{Selection of Plant}

Caesalpinia bonducella (Linn.) Roxb: The plant is a large dioecious thorny shrub found throughout India. The branches are armed with hooks and prickles. The leaves $3 \mathrm{~cm}$ long and the flowers pale yellow in color. The fruits are inflated pods with prickles having 1 or 2 seeds. The seeds of this plant are hard, globular, grey colored, shiny, smooth surface with yellowish white kernel. The seed coat is thick. The plant is known as 'fever nut' or 'bonduc nut'. Several months to years may be required for its germination because of its hardened nature. It is a well known traditional plant used in folklore medicine around the world and especially greater parts of India. The powdered seed kernel of Caesalpinia bonduc is used by the local people of Assam in the treatment of diabetes (Sharma and Das, 2009). All parts of this plant have medicinal properties 
(Kirtikar and Basu, 1988). Due to continuous over exploitation of the plant and destroying its habitat, its number has drastically reduced. Now it is the time to preserve this rare medicinal plant species. It will become extinct if proper steps are not taken for its conservation and are listed under endangered medicinal plant category (Hutton, 2001).

\subsection{Preparation of Plant Extract}

Caesalpinia bonduc (Lin.) Roxb. Plant seeds were collected from the local market in Dharwad. The seeds were shade dried, coarsely powdered using a mixer and sieved to get uniform powder. The powdered material $(500 \mathrm{~g})$ was extracted with $95 \%$ ethanol in Soxhelt apparatus. The extract was then evaporated under reduced pressure to obtain a greenish black jelly residue. The extracts were then stored in airtight glass containers and refrigerated till further use.

\subsection{Acute Toxicity Studies}

The plant extracts often influence toxicities. Hence, acute oral toxicity test for ASECB was carried out to know possible toxicities. When administered orally, ASECB was found to be relatively nontoxic (Ali et. al., 2008). There was no mortality or toxic reactions were noticed with the selected doses among the rats until the end of the study period.

\subsection{Experimental Design}

A total of 36 rats (18 normal, 18 diabetic) were used. The rats were randomly divided into 6 groups. All the experimental rats were placed on normal diet throughout the experiment. Group-I served as normal-control, Group-II served as diabetic-control and both the groups did not received any treatment. Alloxan was administered and induced diabetes in Group-II, V and VI. The experimental animals of Group-III, IV, V and VI were administered with ASECB.

\begin{tabular}{|c|c|c|}
\hline GROUPS & TREATMENTS & DOSES \\
\hline Group-I (06) & Normal-Control & $\begin{array}{l}\text { Administered } 1 \mathrm{ml} \text { distilled water } \\
\text { /rat/day orally for } 21 \text { days }\end{array}$ \\
\hline Group-II (06) & Diabetic-Control & $\begin{array}{l}\text { Administered } 1 \mathrm{ml} \text { distilled } \\
\text { water/rat/day orally for } 21 \text { days }\end{array}$ \\
\hline Group-III (06) & Normal-Treated & $\begin{array}{l}\text { Administered } 200 \mathrm{mg} \text { ASECB } / \mathrm{kg} \\
\text { bw orally/rat } / 1 \mathrm{ml} \text { for } 21 \text { days }\end{array}$ \\
\hline Group-IV (06) & Normal-Treated & $\begin{array}{l}\text { Administered } 400 \mathrm{mg} \text { ASECB } / \mathrm{kg} \\
\text { bw orally/rat } / 1 \mathrm{ml} \text { for } 21 \text { days }\end{array}$ \\
\hline Group-V (06) & Diabetic-Treated & $\begin{array}{l}\text { Administered } 200 \mathrm{mg} \text { ASECB } / \mathrm{kg} \\
\text { bw orally/rat } / 1 \mathrm{ml} \text { for } 21 \text { days }\end{array}$ \\
\hline Group-VI (06) & Diabetic-Treated & $\begin{array}{l}\text { Administered } 400 \mathrm{mg} \text { ASECB } / \mathrm{kg} \\
\text { bw orally/rat } / 1 \mathrm{ml} \text { for } 21 \text { days }\end{array}$ \\
\hline
\end{tabular}

Table. Blood sample collection and biochemical estimation

At the end of the experiment animals were kept overnight fast but the animals had free access of water and sacrificed after a short exposure to sodium pentobarbital. Since the blood collection is at the end of the experiment and terminal, blood samples were collected from each rat into sample tubes by direct cardiac puncture using a $1 \mathrm{ml}$ syringe and a 22 gauge needle which yield a mixture of both arterial and venous blood. Serum was separated by centrifugation of sample and the serum was subjected for biochemical analysis of serum lipid profile and serum protein. Serum lipid profile was determined by standard procedure in an auto analyzer using Ecoline kits (E.merck, Mumbai, India). For the estimation of total protein in serum, Lowry et.al. (1951) method was used.

\subsection{Statistical Evaluation}

All values were expressed as mean \pm S.E. Statistical evaluation was carried out using one-way analysis of variance (ANOVA) (Winer, 1971). P values of $<0.05$ were taken as significant. 


\section{RESUlTS}

\subsection{Estimation of lipid profile}

The detail data in respect of mean levels of total cholesterol (TC), serum triglyceride (TG), High density lipoprotein (HDL), Low density lipoprotein (LDL) and very low density lipoprotein (VLDL) is summarized in Table-1. The mean values of TC, TG, HDL, LDL and VLDL recorded in Group-I (Normal-control) was 83.40 $\pm 6.63,79.40 \pm 5.81,42.28 \pm 2.59,23 \pm 2.98$ and 27.56 \pm 5.72 . A significant increase $(\mathrm{P}<0.05)$ in $\mathrm{TC}, \mathrm{TG}, \mathrm{LDL}, \mathrm{VLDL}$ levels and decrease in HDL level were observed in Group-II (Diabetic-control). The value of TC, TG, HDL, LDL and VLDL recorded in alloxan induced diabetic rats (Group-II) was 166.14 $\pm 26.95,146.28 \pm 17.25,26.76 \pm 1.47$, $125.82 \pm 21.51$ and $75.66 \pm 11.89$. The lipid profile values of normal rats which are administered with different doses (200mg and 400mg) of ASECB (Group-III \& IV) are more or less similar to normal control animals (Group-I). No significant difference in lipid profile in Group-III and IV was noticed in comparison to Group-I (Control).The diabetic rats which are treated orally with 200mg and 400mg ASECB (Group-V \& VI) showed a significant fall $(\mathrm{P}<0.05)$ in the levels of TC, TG, LDL, VLDL and significant elevation in HDL was noticed when compared to untreated diabetic-control animals (Group-II). The administration of plant seed extract to diabetic experimental animals almost normalizes the levels of TC \& TG. Above referred data of statistical significant $(\mathrm{P}<0.05)$ decrease in the levels of TC, TG, LDL, VLDL and increase in HDL after supplementation of ASECB indicates the hypolipidemic action of the plant seed extract. Further, the results reveal that the higher dose of $400 \mathrm{mg}$ is more effective than a dose of $200 \mathrm{mg}$.

\subsection{Estimation of Total Protein}

Table-1 besides lipid profile also depicts the levels of total proteins. The protein concentration of normal-control rats (Group-I) was $8.14 \pm 0.13$. The level of total protein in serum of alloxan induced diabetic rats (Group-II) declined to $4.72 \pm 0.23$. This sharp fall was statistically significant $(\mathrm{P}<0.05)$ compared with control rats. . The total protein concentration level recorded in rats of Group-III \& IV which are normal but administered with $200 \mathrm{mg}$ and $400 \mathrm{mg}$ ASECB respectively was almost similar to that of normal control rats indicating that the plant extract has no side effects. The diabetic induced rats after administration of ASECB (Group-V \& VI) showed a sharp elevation in protein level. The total protein level recorded in serum of ASECB treated rats of Group-V \& VI were $7.36 \pm 0.22$ and $7.80 \pm 0.12$ respectively, which was statistically significant $(\mathrm{P}<0.05)$ compared to diabetic-control rats (Group-II). The increase in the levels of protein concentration observed in experimental animals of Group-V and Group-VI, which are administered with $200 \mathrm{mg}, 400 \mathrm{mg}$ ASECB was mainly due to ASECB.The elevation was however not to the level of normal-control rats and there was no significant difference in the level of total protein between group-I with that of Group-V \& VI.

\section{DisCuSSION}

Plant products are considered to be less toxic and free from side effects than synthetic one (Brinker, 1998). Many herbs and plant products have been shown to have hypolipidemic property (Chattopadhyaya and Bandyopadhyay, 2005). Earlier DM has been treated orally in folk medicine with variety of plant extracts. In India a number of plants are mentioned in Ayurveda for the treatment of diabetes and some of them have been tested experimentally (Chattopadhyaya, 1993). Caesalpinia bonducella is a popular medicinal plant traditionally used in the management of diabetes. In the present investigation an attempt was made to evaluate the antihyperlipidemic effect of ASECB and to find out whether the seeds of this plant have cholesterol and triglyceride lowering property or not.

Diabetes affects both glucose and lipid metabolism (Sperling et. al., 2000). In the present investigation, a significant increase in LDL and VLDL level in diabetic control rats (Group-II) was noticed. The increased levels of LDL and VLDL in the diabetic animals might be due to over production of LDL and VLDL by the liver due to the stimulation of hepatic triglyceride synthesis as a result of free fatty acid influx (Coppack, 1994). 
Williamson, (2002) has reported that the seeds of Caesalpinia bonduc (Lin.) Roxb. are found to contain various chemical constituents such as furanoditerpenses-caesalpin- $\alpha$, caesalpin- $Y$, caesalpin- $\varrho$, caesalpin- $\epsilon$, caesalpin and caesalpin-F. Fatty acids- palmitic, stearic, octadeca-4enoic and octadeca-2-4-dienoic, lignocenic, oleic and linoleic acids, phytosterinin, $\beta$-sitosterol, homoisoflavone, bonducellin, amino acids-aspartic acid, arginine and citrulline, carbohydrates starch, sucrose, $\beta$-carotene, glycoside bonducin, gums and resins. The hypolipidemic effect produced by the ASECB as observed in the present work may probably be due to presence of any one or combination of different phyto chemical constituents referred to above. Leontowicz et. al., (2002) and Ogawa et. al., (2005) has also reported that secondary metabolites such as saponins, flavonoids, phenolic compounds and triterpenoid have hypolipidemic activity.

In the present investigation, the high cholesterol level developed in diabetic induced rats of Group-II was significantly declined in experimental rats of Group-V and VI which are orally administrated with ASECB for 21 days. This hypocholesterolaemic effect of the extract could possibly be related to its amino acid composition since Kritchevsky, ( 1978) has showed that soya bean decreased cholesterol levels in rabbits and related this effect of amino acid pattern of this seed particularly lysine/arginine ratio.

In our earlier work (Sagar and Ahmed, 2014), we have reported that the islets were significantly decreased in diameter and many of the beta cells destroyed in alloxan induced diabetic rats which have resulted in deficiency in the production of insulin. Ribes et. al., 1987, Venkateshwarulu, 1993 has reported the increased levels of cholesterol and triglycerides in diabetic rats due to insulin deficiency. Further Ghosh-Sumana and Suryavamshi, (2001) has too similarly observed that hypo secretion of insulin leads to various metabolic aberrations in animals' viz. decreased protein concentration. Diabetes induced hyperlipidimia may be due to low level of insulin or due to interference in insulin action (Kishalay et. al., 2010). Insulin deficiency causes excessive catabolism of protein and the amino acid released are used for gluconeogenisis (Vasantha kumari and Shyamala devi, 1998) The abnormalities in lipid metabolism lead to elevation in the levels of serum lipid and lipoprotein that in turn play an important role in occurrence of premature and severe atherosclerosis, which affects patients with diabetes (Ravi et. al., 2005). Hence, cardiac complications during diabetic conditions can be prevented by maintaining normal lipid profile.

The higher lipid levels seen in diabetic rats was due to increased mobilization of free fatty acids from peripheral depots and also due to lipolysis caused by hormones (Ei-Soud et. al., 2007). The levels of TC, TG, LDL and VLDL were found to be significantly reduced in the treated diabetic animals. This might be due to the reduced hepatic triglyceride synthesis and or reduced lipolysis that might be due to the increase in serum insulin level in treated rats. The HDL increased significantly in the treated rats indicating a reversed atherogenic risk (Sivaraj et. al., 2009)

Decreased protein level and increased lipid profile were noted in diabetic rats and HDL was decreased. This may be due to excessive catabolism of protein and amino acids that are released and used for gluconeogenesis. This also stimulates lipolysis in adipose tissue which gives rise to hyperlipidemia (Nanda et. al., 2007)The diversity of all the above said actions may be responsible for the hypolipidemic action of the extract.

\section{Conclusion}

In conclusion the studies referred supra demonstrated that continuous oral administration of ASECB for 21 days to alloxan induced diabetic rats has beneficial effect in preventing the elevation of serum lipids level. Thus the Caesalpinia bonducella seed extract serves as good oral hypolipidemic agent and can be used to manage diabetic complications by improving lipid profile.

Additional studies are warranted to fully understand as to how ASECB works and by what mechanism the extract is able to act as hypolipidemic agent and biological evaluation of actual active principle in the ASECB.

\section{ACKNOWLEDGEMENTS}

The first author is grateful to the Principal and Chairman, Veerashaiva College, Ballari for permitting to carry out this piece of research work and sincere thanks to Mr. Subhas Bijjaragi, 
Research Scholar, Department of Zoology, KUD for his help during this study". Further, the research facilities provided by the PG Dept. of Zoology, KUD is gratefully acknowledged.

Table1. Effect of treatment with alcoholic seed extract of Caesalpinia bonducella (ASECB) on Lipid profile and Protein concentration in control and alloxan induced diabetic male albino rats.

\begin{tabular}{|l|l|l|l|l|l|l|}
\hline Groups & $\begin{array}{l}\text { Cholesterol } \\
(\mathbf{m g} / \mathbf{d l})\end{array}$ & $\begin{array}{l}\text { S.Triglyceride } \\
\mathbf{m g} / \mathbf{d l})\end{array}$ & $\begin{array}{l}\text { S.HDL } \\
(\mathbf{m g} / \mathbf{d l})\end{array}$ & S.LDL (mg/dl) & $\begin{array}{l}\text { S.VLDL } \\
(\mathbf{m g} / \mathbf{d l})\end{array}$ & $\begin{array}{l}\text { Protein } \\
\text { level } \\
(\mathbf{g m} . / \mathbf{d l})\end{array}$ \\
\hline $\begin{array}{l}\text { Group-I } \\
\text { (Normal- control) }\end{array}$ & $83.40 \pm 6.63^{\mathrm{a}}$ & $79.40 \pm 5.81^{\mathrm{a}}$ & $42.28 \pm 2.59^{\mathrm{a}}$ & $23.0 \pm 2.98^{\mathrm{a}}$ & $27.56 \pm 5.72^{\mathrm{a}}$ & $8.14 \pm 0.13^{\mathrm{a}}$ \\
\hline $\begin{array}{l}\text { Group-II (Diabetic- } \\
\text { control) }\end{array}$ & $166.14 \pm 26.95^{\mathrm{b}}$ & $146.28 \pm 17.25^{\mathrm{b}}$ & $26.76 \pm 1.47^{\mathrm{b}}$ & $125.82 \pm 21.51^{\mathrm{b}}$ & $75.66 \pm 11.89^{\mathrm{b}}$ & $4.72 \pm 0.23^{\mathrm{b}}$ \\
\hline $\begin{array}{l}\text { Group-III } \\
\text { (Normal+200mg } \\
\text { ASECB) }\end{array}$ & $82.16 \pm 5.48^{\mathrm{a}}$ & $79.40 \pm 5.26^{\mathrm{a}}$ & $42.06 \pm 3.09^{\mathrm{a}}$ & $22.62 \pm 2.15^{\mathrm{a}}$ & $27.44 \pm 5.47^{\mathrm{a}}$ & $7.78 \pm 0.18^{\mathrm{a}}$ \\
\hline $\begin{array}{l}\text { Group-IV } \\
\text { (Normal+400mg } \\
\text { ASECB) }\end{array}$ & $84.33 \pm 6.66^{\mathrm{a}}$ & $79.21 \pm 9.81^{\mathrm{a}}$ & $43.11 \pm 5.32^{\mathrm{a}}$ & $27.26 \pm 2.33^{\mathrm{a}}$ & $28.61 \pm 5.51^{\mathrm{a}}$ & $8.11 \pm 0.21^{\mathrm{a}}$ \\
\hline $\begin{array}{l}\text { Group-V } \\
\text { (Diabetic+200mg } \\
\text { ASECB) }\end{array}$ & $95.12 \pm 8.45^{\mathrm{a}}$ & $92.46 \pm 8.55^{\mathrm{a}}$ & $39.64 \pm 3.39^{\mathrm{a}}$ & $74.86 \pm 8.44^{\mathrm{c}}$ & $35.06 \pm 4.69^{\mathrm{c}}$ & $7.36 \pm 0.22^{\mathrm{a}}$ \\
\hline $\begin{array}{l}\text { Group-VI } \\
\text { (Diabetic+400mg } \\
\text { ASECB) }\end{array}$ & $87.50 \pm 9.32^{\mathrm{a}}$ & $83.28 \pm 10.19^{\mathrm{a}}$ & $42.50 \pm 2.46^{\mathrm{a}}$ & $59.46 \pm 6.05^{\mathrm{a}}$ & $29.90 \pm 3.19^{\mathrm{a}}$ & $7.80 \pm 0.12^{\mathrm{a}}$ \\
\hline
\end{tabular}

Note: Groups with similar superscript letters $(a, b, c)$ in the given column indicates not significant. While groups with dissimilar superscript letter indicate significantly different from each other.

\section{REFERENCES}

Ali, A., Rao, N. V., Shalam, M., Gouda, T. S., Babu, J. M. and Shantakumar, S. M. (2008). Anxiolytic activity of seed extract of Caesalpinia bonducella (Roxb.) in laboratory animals. The Internet J. Pharmacology (Serial online). 5: 2.

A. Sivaaraj, K. Devi, S.. Palani, P. Vinoth kumar, B. Senthiln kumar, E. David.( 2009) Antihyper glycemic and anti-hyperlipidemic effect of combined plant extract of Cassia auriculata and Aegle marmelos in streptozotocin (STZ) induced diabetyic albino rats. International Journal of Pharm Tech Research 1:4, pp 1010-1016..

Anuradha, K., Hota, D. and Pandhi, P. (2001). Investigation of central mechanism of insulin induced hypoglycemic convulsions in mice. Indian J. Exp Biol. 39: 500-502.

Bailey CJ, Day C. Traditional plant medicines as treatments for diabetes. Diabetes Care. (1989), 553-564.

Best CH, Taylor NB. (1989),Biological effects of insulin. In: Willions W, Wilkins, editors. Physiological basis of medical practice. London: Cambridge University Press.

Boyle, J. P., Honeycutt, A. A., Narayan, K. M., Hoerger, T. J., Geiss,I. S., Chen, H. and Thompson, T. J. (2001). Projection of diabetes burden through 2050: Impact of changing demography and disease prevalence in the U. S. Diabetes Care. 24: 1936-40.

Brinker, F. (1998), Herb contributions and drug interactions, 2nd Ed.; Eclectic Medical Publications: Sandy OR USA,; pp. 36-82.

Chattopadhyay RR (1993) Hypoglycemic effect of $O$. sanctum leaf extract in normal and streptozotocin diabetic rats. Indian Journal of Experimental Biology. 31: 891-893.

Chattopadhyay R.R. and Bandyopadhyay M. (2005) Effect of Azardirachta indica on serum lipid profile changes in normal and streptozotocin induced diabetic rats, Afr. J. Biomed. Res., , 8, 101-104.

Coppack S.W, Jenson M.D, Miles J.M. (1994),In vivo regulation of lipolysis in human. J. lipid Res.; 35: 177-193.

Desai, A. C. and Bhide, M. B. (1985), Hypoglycemic activity of Hamiltonia suaveolens. Indian J. Med. Res. 81: 86-91. 
Devaki, K., Beulah, U., Akila, G., Narmadha, R. and Gopalakrishnan V. K. (2011). Glucose lowering effect of aqueous extract of Bauhinia tomentosa L. on alloxan induced type 2 diabetes mellitus in Wistar albino rats. J. Basic and Clinical Pharmacy. 2: 167-174.

Ei-Sooud NH, Khalil MY, Oraby FS, Farrag AR. (2007), Antidiabetic effects of Fenugreek alkaloid extract in streptozotocin induced hypoglycemic rats. J App Sci; 3: 1073-83.

Ghosh Sumana, Suryawanshi SA.( 2001), Effect of Vinca rosea extracts in treatment of alloxan diabetic rats in male albino rats. Indian J Exp Biol; 39: 748.

Gray Alison, M., Abdul Wahab, Y. H. A. and Flatt, P. R. (1999). The traditional plant treatment, Sambucus nigra (elder), exhibits insulin like and insulin-releasing actions in vitro. J. Nutr. 130: $15-20$.

Holman, R. R. and Turner, R. C. (1991). Oral Agents and insulin in the treatment of Diabetes. Blackwell Oxford, pp. 467-469.

Hruban, R. H. and Wilentz, R. E. (2004). "The Endocrine Pancreas" in robbins and cortran pathologic basis of disease. Saunder Company, Philadelphia, London. 1st Edition. pp. 939953.

Hutton I.(2001) Rare plant surveys- Report to NSW scientific committee (Lord Howe Island, Sydney).

Lowry OH, Rosebrough N J, Farr AL, Randall RJ. (1951), Protein measurement with Folins phenilreagent. J Biol Chem ; 193:265.

King, H., Aubert, R. E. and Herman, W. H. (1998). Global burden of diabetetes 1995-2025: Prevalence, Numerical estimates and projections. Diabetes Care. 21: 1414-31.

Kirtikar, K. R. and Basu, B. D. (1988), Indian medicinal plants. 2nd Edition. International Book Distributors, Dehradun. pp. 839-902.

Kishalay Jana, Kausik Chatterjee, Tushar Kanti Bera, Soumyajit Maiti, Debasis De, Kazi Monjur ali and Debidas Ghosh, (2010), Antihyperglycemic effects of hydro-methanolic extract of seed of Caesalpinia bonduc in streptozotocin induced diabetic male albino rat. International journal of PharmTech Research, 2:4, 2234-2242.

Kritchevsky D. (1978), Soya-saponins and plasma cholesterol levels. Lancet.; 1:610.

Larner, J. (1985). Insulin and Hypoglycemic drugs Glucagon. In: The Pharmacological Basis of Therapeutics, Gilman, A.G., L.S. Goodman, T.W. Rall and F. Murad (Eds.). Macmillian, New York, pp. 1490-1516.

Leontowicz H, Gorinstein S, Lojek A, Leontowicz M, Ciz M, Soliva-Fortuny R, et al. (2002), Comparative content of some bioactive compounds in apples, peaches and pears and their influence on lipids and antioxidant capacity in rats. J Nutr Biochem.; 13: 603-10.

Li WL, Zheng, H. C., Bukuru, J. and Kimpe, N. D. (2004). Natural medicine used in the traditional Chinese medical system for therapy of diabetes mellitus. J. Ethnopharmacol. 92: $1-21$.

Nandhakumar Jothivel, Sethumathi Pudhupalayam Ponnusamy, Malini Appachi, Sengottuvelu Singaravel, Duraisamy Rasilingam, Karathikeyan Deivasigamani and Sivakumar Thangavel. (2007), Anti-diabetic activity of methanol leaf extract of Costus pictus D.Don in alloxaninduced diabetic rats. Journal of Health Science, 53(6) 655-663.

Ogawa H, Nakamura R, Baba K. (2005), Beneficial effect of laserpitin, a coumarin compound from Angelica keiskei, on lipid metabolism in stroke-prone spontaneously hypersensitive rats. Clin Exp Pharmacol Physiol; 32: 1104-09.

Patwardhan, B., Vaidya, A. D. B. and Chorghade, M. (2004). Ayurveda and natural products drug discovery. Curr. sci. 86: 789-799.

zao, K., Giri, R., Kesavulu, M. M. and Apparao, C. (1997). Herbal medicine in the management of z S, Subramanian S. (2005), Anatihyperlipidemia effect of Eugenia Jambolana seed kernel on streptozotocin induced diabetes in rats. Food chem.. Toxicol; 43: 1433-39

Ribes G, Dacosta C, Loubatieres-MarianiMM. (1987), Hypocholesterolemic and hypotriglyceridemic effects of sub fractions from Fenugreek seeds in diabetic dogs. Phytother Res; 1-38. 
Said, O., fulder, S., Khalil, K., Azaizeh, H., Kassis, E. and Saad, B. (2007). Maintaining a physiological blood glucose level with "Glucolevel", a combination of four antidiabetes plants in the traditional Arab herbal medicine. Evid Based Complement Alternat Med. 5: 421-428.

Sharma S.B., Nasir, A., Prabhu, K.M., Murthy, P.S., Dev, G. (2003), Hypoglycaemic and hypolipidemic effect of ethanolic extract of seeds of Eugenia jambolana in alloxan-induced diabetic rats. J. Ethnopharmacol. 85, 201-206.

Sharma, G. and Das, S. (2009), Hypoglycemic action of Seed kernel of Caesalpinia bonducella Fleming in Normal and Alloxan-Induced Diabetic Albino Rats. The Internet J. Pharmacology. 6: 2.

Sperling M.A., Saunders P.A. Diabetes mellitus in: R.E. Behrman R.M, Kliegman H.B, (2000), Jenson (Eds) Nelson text book of Pediatrics ; 1767-1791.

Valiathan, M. S. (1998). Healing plants. Curr Sci. 75: 1122-1126.

Vedavyasa sagar and Nazeer ahmed R. (2014), Studies on the beta cells of islets of langerhans of alloxan induced diabetic albino rats treated with alcoholic seed extract of Caesalpinia bonducella. The Biosan;

Venkateshwarlu V, Kokate C.K., Rambhau D, Veerasham C. (1993), Antidiabiatic activity of roots of Salacia macrosperma. Planta Med; 59: 391.

Vasantha kumara, V. and Shyamala devi, C.S. (1998), Biochemical evaluation of "Tara Keswara Rasa"- An anti diabetic drug in Rats, Indian Drugs, 35, 140-143.

Vetrichelvan, T., Jagadeesan, M. and Uma Devi, B. A. (2002). Antidiabetic activity of alcohol extract of Celosia argentea Linn. Seeds in rats. Bio. Pharm. Bull. 25: 526-528.

Wild, S. G., Folic, A., Green, R. and King, H. (2004). Global prevalence of diabetes. Estimated for the year 2000 and projection for 2030, Diabetic care. 127: 1047-1054.

Winer, B. J. (1971), Statistical principles experimental design, Mc Graw. Hill. New York.

Williamson, E.M. (2002), Major herbs of Ayurveda. The Dabur Research Foundations \& Dabur Ayurvet Limited, India, p. 83. 